\title{
Penerapan Teorema Bayes Untuk Mengidentifikasi Penyakit Tanaman Bonsai
}

\author{
Rollando Govintdes ${ }^{1}$, M.revin Reginal ${ }^{2}$, Mokhamad Gustiawan ${ }^{3}$, \\ Ristu Juli Yudianto ${ }^{4}$, Ahmad Surya $^{5}$, Sari susanti ${ }^{6}$ \\ Rollandogovintdes96@gmail.com¹, Babaw17@gmail.com² \\ juliyudiantorestu@gmail.com ${ }^{4}$, ifan.surya26@gmail.com ${ }^{5}$, sarisusanti@ars.ac.id 6 . \\ Teknik Informatika, Fakultas Teknologi Informasi, Adhirajasa Reswara Sanjaya (ARS) \\ Antapani, Jl. Terusan Sekolah No.1-2, Cicaheum, Kec. Kiaracondong \\ Kota Bandung, Jawa Barat 40282
}

\begin{abstract}
Abstrak - Tanaman Bonsai merupakan tanaman atau pohon yang dikerdilkan di dalam pot dangkal dengan tujuan membuat miniatur dari bentuk asli pohon besar yang sudah tua di alam bebas. Tanaman Bonsai sangat rentan terhadap serangan hama dan penyakit terutama apabila bonsai tidak dirawat dengan baik. Dimana cara merawat tanaman bonsai mulai dari pemupukan sampai pembentukan harus sangat diperhatikan dan sangat teliti, meski perawatan tanaman ini sama saja seperti perawatan tanaman lainnya. keberadaan hama dan penyakit pada bonsai tentunya dapat mengurangi keindahan dari bonsai tersebut. Oleh karena itu penanaman dan pemeliharaan bonsai memerlukan ketelitian dan kesabaran, berbeda dengan menanam tanaman lainnya. karena bentuknya yang indah dan menarik dan biasa dipajang di halaman rumah sebagai hiasan untuk menambah keindahan rumah, sehingga orang yang melihat akan merasa tertarik. Tujuan yang di dapat memberikan informasi dalam mendiagnosa penyakit tanaman bonsai dan mendapatkan hasil diagnosa yang tepat dan akurat.
\end{abstract}

Kata Kunci : Bonsai, Teorema Bayes

Abstract - Bonsai plants are plants or trees that are dwarfed in shallow pots with the aim of making miniatures of the original form of large trees that are old in the wild. Bonsai plants are particularly susceptible to pest and disease attacks especially if bonsai is not well cared for. Where how to care for bonsai plants ranging from fertilization to formation should be very careful and very careful, although the treatment of this plant is the same as the treatment of other plants. the presence of pests and diseases in bonsai can certainly reduce the beauty of the bonsai. Therefore planting and maintaining bonsai requires thoroughness and patience, in contrast to planting other plants. because the shape is beautiful and interesting and usually displayed in the yard as a decoration to add to the beauty of the house, so that people who see will feel interested. The purpose of which can provide information in diagnosing bonsai and get the right diagnosis and accurate results.

Keywords : Bonsai, Teorema Bayes

\section{Pendahuluan}

Tanaman Bonsai merupakan tanaman yang dikerdilkan dan biasanya bisa ditanam dalam sebuah pot tanaman. Biasanya tanaman bonsai dibuat sebagai miniatur dari bentuk asli pohon besar yang sudah tua di alam bebas untuk hiasan maupun sebagai tujuan pembelajaran. Dimana cara merawat tanaman bonsai mulai dari pemupukan sampai pembentukan harus sangat diperhatikan dan sangat teliti, meski perawatan tanaman ini sama saja seperti perawatan tanaman lainnya, tetapi yang sulit dari merawat tanaman ini adalah dari segi pembentukannya, dimana harus memberi arah pembentukan dan mempertahankan bentuk dari tanaman tersebut. Ada beragam penyakit yang menyerang tanaman bonsai, Penyakit merupakan suatu gangguan pada tanaman yang menghambat pertumbuhan pada suatu tumbuhan.Oleh karna itu penulis ingin membangun sistem pakar secara manual dalam mengidentifikasikan penyakit tanaman bonsai.[1].

Oleh karena itu penanaman dan pemeliharaan bonsai memerlukan ketelitian dan kesabaran, berbeda dengan menanam tanaman lainnya. Bonsai ini ditanam dipot yang beraneka ragam bentuk dan ukurannya, karena bentuknya yang indah dan menarik dan biasa dipajang di halaman rumah sebagai hiasan untuk menambah keindahan rumah, sehingga orang yang melihat akan merasa tertarik.

\section{Landasan Teori}

A. Sistem Pakar

Sistem pakar merupakan cabang dari Artificial Intelligence (AI) yang cukup tua karena sistem ini mulai dikembangkan pada pertengahan 1960. Istilah sistem pakar berasal dari istilah knowledge-based expert system. Istilah ini muncul karena untuk memecahkan masalah, sistem pakar menggunakan pengetahuan seorang pakar yang dimasukkan ke dalam komputer. Seseorang yang bukan pakar menggunakan sistem pakar untuk 
meningkatkan kemampuan pemecahan masalah, sedangkan seorang pakar menggunakan sistem pakar untuk knowledge assistant[3].

\subsection{Penyakit Tanaman Bonsai}

Ada beberapa penyakit tanaman yang umumnya menyerang tanaman Bonsai, antara lain[4]:

1. Klorosis

Gejalanya daun menjadi kuning kecuali tulang daunnya yang masih tetap hijau.Mungkin gejala ini akibat kekurangan zat besi. Jadi sebaiknya tanaman diberi pupuk yang mengandung zat besi.

2. Embun Tepung

Penyakit ini akibat serangan jamur. Gejalanya bisa diidentifikasi dari adanya tepung berwarna putih atau abau-abu pada permuakaan atas daun. Biasanya hal itu terjadi bila temperature tinggi, dikombinasi dengan kurangnya sirkulasi udara atau kelembapan yang terlalu tinggi.

3. Busuk Akar

Busuk akar paling umum terjadi pada bonsai, tapi penyebabnya juga sangat bervariasi. Penyakit ini bisa terjadi sebagai akibat dari kesalahan pemeliharaan tanaman. Mungkin karena kebanyakan disiram, terlalu banyak diberikan pupuk, atau pencampuran tanah yang salah.

4. Thrips

Serangga lain yang memakan bagian bawah daun. Thrips menusuk daun, bunga, atau batang yang menyedot getah yang keluar.

5. Juniper Twig Girdler

Masalah utama bagi banyak pembonsai. Kerusakan yang sebenarnya di lakukan oleh larva ngengat kecil. 6. Hama

Kutu daun pada musim semi kutu daun bias menjadi masalah nyata, terutama pada daun maple yang baru muncul. Sebagian besar yang kita lihat berwarna hijau tetapi beberapa berwarna abu-abu/hitam.

\subsection{Teorema Bayes}

Metode bayes juga memandang parameter sebagai variable yang menggambarkan pengetahuan awal tentang parameter sebelum pengamatan dilakukan dan dinyatakan dalam suatu distribusi yang disebut dengan distribusi prior.Setelah pengamatan dilakukan, informasi dalam distribusi prior dikombinasikan dengan data sampel melalui teorema bayes[2]. Sesuai dengan probabilitas subjektif, bila seseorang mengamati kejadian dan mempunyai keyakinan bahwa ada kemungkinan B akan muncul, maka probabilitas B disebut prior. Sedangkan ada informasi tambahan bahwa misalkan kejadian A telah muncul, mungkin akan terjadi perubahan terhadap perkiraan semula mengenai kemungkinan B untuk muncul. Probabilitas untuk B sekarang adalah probabilitas bersyarat akibat A dan disebut sebagai probabilitas posterior.[3]

\section{Metode Penelitian}

Metode yang di gunakan Metode Teorema Bayes jenis metode yang terdapat pada sistem pakar telah banyak digunakan untuk menemukan solusi permasalahan yang berkaitan tentang probabilitas termasuk penerapan dalam pendeteksian penyakit[5]. Thomas Bayes, menggambarkan hubungan antara peluang bersyarat dari dua kejadian merupakan salah satu cara yang baik mengatasi ketidakpastian data dengan menggunakan formula bayes yang dinyatakan dengan rumus sebagai berikut[6]:

Keterangan :

$$
P(H \mid E)=1 \frac{P(E \mid H) \cdot(H)}{P(E)}
$$

$\mathrm{P}(\mathrm{H} \mid \mathrm{E})=$ probabilitas hipotesis $\mathrm{H}$ jika diberikan evidence $\mathrm{E}$

$\mathrm{P}(\mathrm{E} \mid \mathrm{H})=$ probailitas munculnya evidence $\mathrm{E}$ jika diketahui hipotesis $\mathrm{H}$

$\mathrm{P}(\mathrm{H})=$ probabilitas $\mathrm{H}$ tanpa mengandung evidence apapun

$\mathrm{P}(\mathrm{E})=$ probabilitas evidence

\section{Hasil Dan Pembahasan}

Sistem pakar untuk mendiagnosa penyakit tanaman Bonsai ini menggunakan metode Teorema Bayes. Proses perhitungan menggunakan metode Teorema Bayes untuk memperoleh persentase tingkat kepastian. 
Tabel 1. Data Gejala

\begin{tabular}{|c|c|c|c|}
\hline \\
\hline No. & $\begin{array}{c}\text { Kode } \\
\text { Gejala }\end{array}$ & Nama Gejala & $\begin{array}{c}\text { Nilai Bobot } \\
\text { Pakar }\end{array}$ \\
\hline 1 & G1 & $\begin{array}{l}\text { Daun kering atau } \\
\text { menggulung }\end{array}$ & 0.6 \\
\hline 2 & $\mathrm{G} 2$ & $\begin{array}{c}\text { Daun berwarna } \\
\text { coklat }\end{array}$ & 0.8 \\
\hline 3 & G3 & $\begin{array}{c}\text { Daun dan } \\
\text { batangnya lemah }\end{array}$ & 0.8 \\
\hline 4 & G4 & $\begin{array}{c}\text { Tidak tumbuh } \\
\text { daun yang baru }\end{array}$ & 0.6 \\
\hline 5 & G5 & $\begin{array}{c}\text { Daunnya } \\
\text { berlubang-lubang }\end{array}$ & 1 \\
\hline 6 & G6 & $\begin{array}{l}\text { Terdapat } \\
\text { kotorana ulat di } \\
\text { permukaannya }\end{array}$ & 0.8 \\
\hline 7 & G7 & $\begin{array}{l}\text { Kuncup gagal } \\
\text { menjadi bunga } \\
\text { dan rontok }\end{array}$ & 0.6 \\
\hline 8 & G8 & $\begin{array}{l}\text { Bercak-bercak } \\
\text { pada daun } \\
\text { kemudian } \\
\text { melepuh dan } \\
\text { rontok }\end{array}$ & 0.8 \\
\hline 9 & G9 & $\begin{array}{c}\text { Permukaan daun } \\
\text { atas maupun } \\
\text { bawah menjadi } \\
\text { hitam }\end{array}$ & 1 \\
\hline 10 & G10 & $\begin{array}{c}\text { Dikerumuni } \\
\text { semut, kemudian } \\
\text { terdapat telur } \\
\text { lalat di } \\
\text { permukaan } \\
\text { bawah daun } \\
\end{array}$ & 0.6 \\
\hline 11 & G11 & Tanaman Layu & 0.8 \\
\hline 12 & G12 & Mahkota rontok & $\mathbf{1}$ \\
\hline 13 & G13 & $\begin{array}{l}\text { Pucuk daun } \\
\text { keriting }\end{array}$ & 0.6 \\
\hline
\end{tabular}




\begin{tabular}{|c|c|c|c|}
\hline $\mathbf{1 4}$ & G14 & $\begin{array}{c}\text { Daun menguning } \\
\text { dan sobek }\end{array}$ & $\mathbf{1}$ \\
\hline $\mathbf{1 5}$ & G15 & $\begin{array}{c}\text { Tangkai dan akar } \\
\text { membusuk }\end{array}$ & $\mathbf{0 . 8}$ \\
\hline $\mathbf{1 6}$ & G16 & $\begin{array}{c}\text { Terdapat hewan } \\
\text { cabuk didalam } \\
\text { kulit batang }\end{array}$ & $\mathbf{0 . 8}$ \\
\hline $\mathbf{1 7}$ & G17 & $\begin{array}{c}\text { Kalau disiram air } \\
\text { tidak cepat habis }\end{array}$ & $\mathbf{0 . 6}$ \\
\hline
\end{tabular}

Tabel 2. Diagnosa

\begin{tabular}{|c|c|c|c|}
\hline No & $\begin{array}{c}\text { Kode } \\
\text { Diagnosa }\end{array}$ & Gejala dialami & Diagnosa \\
\hline 1 & D001 & $\begin{array}{c}\text { Daun kering atau } \\
\text { menggulung(G1), } \\
\text { daun dan } \\
\text { batangnya }\end{array}$ & $? ? ?$ \\
& & lemah(G3), & \\
& & daunnya & \\
& & berlubang- & \\
& & lubang(G5), & \\
& & kuncup gagal & \\
& & menjadi bunga & \\
& & dan rontok(G7), & \\
& & ,pucuk daun & \\
& & keriting(G13), & \\
\hline
\end{tabular}

Dibawah ini adalah hasil perhitungan manual diagnosa penyakit tanaman bonsai menggunakan metode teorema bayes.

Langkah ke-1: Menghitung total nilai bobot gejala yang di alami:

a. Jenis gejala :

Daun kering atau menggulung $(\mathrm{G} 1)=0.6$

daun dan batangnya lemah $(\mathrm{G} 03)=0.8$

daunnya berlubang-lubang (G5) = 1

kuncup gagal menjadi bunga dan $\operatorname{rontok}(\mathrm{G} 7)=0.6$

pucuk daun keriting $(\mathrm{G} 13)=0.6$

Total bobot gejala $=0.6+0.8+1+0.6+0.6=3.6$

Langkah ke-2 Menghitung nilai probabilitas gejala terhadap penyakit:

a. Jenis gejala:

$(\mathrm{P} \mid \mathrm{H} 1)=0.6 / 3.6=0.17$

$(\mathrm{P} \mid \mathrm{H} 2)=0.8 / 3.6=0.2$

$(\mathrm{P} \mid \mathrm{H} 3)=1 / 3.6=0.28$

$(\mathrm{P} \mid \mathrm{H} 4)=0.6 / 3.6=0.17$

$(\mathrm{P} \mid \mathrm{H} 5)=0.6 / 3.6=0.17$

$\mathrm{P}(\mathrm{E} \mid \mathrm{HK}) \times \mathrm{P}(\mathrm{HK})=(0.6 * 0.17)+(0.8 * 0.2)+(1 * 0.28)+(0.6 * 0.17)+(0.6 * 0.17)=0.102+0.16+0.28+0.102$ $+0.102=0.746$ 
Langkah ke-3 Menghitung nilai bayes akhir

a. Jenis gejala:

$\mathrm{P}(\mathrm{H} 1 \mid \mathrm{E})=\left(0.6^{*} 0.17\right) / 0.746=0.13$

$\mathrm{P}(\mathrm{H} 2 \mid \mathrm{E})=(0.8 * 0.2) / 0.746=0.21$

$\mathrm{P}(\mathrm{H} 3 \mid \mathrm{E})=(1 * 0.28) / 0.746=0.37$

$\mathrm{P}(\mathrm{H} 4 \mid \mathrm{E})=\left(0.6^{*} 0.17\right) / 0.746=0.13$

$\mathrm{P}(\mathrm{H} 5 \mid \mathrm{E})=\left(0.6^{*} 0.17\right) / 0.746=0.13$

$\sum$ Bayes $=(0.6 * 0.13)+(0.8 * 0.21)+(1 * 0.37)+(0.6 * 0.13)+(0.6 * 0.13)=0.078+0.168+0.37+0,078+0.078=$ 0.772 (hasil bayes)

Langkah ke-4: Mencari nilai probabilitas yang paling tinggi:

$\operatorname{Max}=0.772$

Jadi dari proses yang telah dilakukan, maka penyakit gejala pada tanaman bonsai dengan nilai bayes 0.772 .

\section{Kesimpulan}

Dari hasil penelitian yang telah dilakukan, maka dapat diambil beberapa kesimpulan antara lain:

1. Sistem pakar ini dapat mendiagnosa penyakit tanaman bonsai berdasarkan gejala-gejala yang dipilih pada halaman diagnosa.

2. Memberikan informasi dalam mendiagnosa penyakit tanaman bonsai dan mendapatkan hasil diagnosa yang tepat dan akurat.

3. Dapat membantu masyarakat yang mempunyai tanaman bonsai untuk mendiagnosa penyakit pada tanaman bonsai.

\section{Daftar Pustaka}

[1] A. Anita, R. Rodhy, S. Ningsih, and D. Solin, "Penerapan Metode Forward Chaining Dan Certainty Factor Untuk Diagnosa Penyakit Pada Tanaman Bonsai," JGK (Jurnal Guru Kita), vol. 3, no. 2, pp. 187-194, 2019.

[2] R. Noviani and S. Sulindawaty, "Sistem Pakar Mendiagnosa Gizi Buruk Pada Balita Menggunakan Teorema Bayes," J. Nas. Komputasi dan Teknol. Inf., vol. 3, no. 2, pp. 163-169, 2020.

[3] P. Studi Sistem Informasi and S. Triguna Dharma, "SISTEM PAKAR UNTUK MENDIAGNOSA PENYAKIT ANEMIA DENGAN MENGGUNAKAN METODE TEOREMA BAYES * Trinanda Syahputra \#1 , Muhammad Dahria \#2 , Prilla Desila Putri \#3,” Saintikom, vol. 16, no. 3, pp. 284-294, 2017.

[4] Dwilestari, S., \& Nurmiati, S. (2018). Sistem Pakar Penentuan Style Pada Tanaman Bonsai Menggunakan Metode Certainty Factor. Sainstech: Jurnal Penelitian dan Pengkajian Sains dan Teknologi, 28(2).

[5] Fadillah, M. R., Andika, B., \& Saripurna, D. (2020). Sistem Pakar Mendiagnosa Penyakit Dan Hama Penyerang Tanaman Bougenville Dengan Metode Teorema Bayes. Jurnal SAINTIKOM (Jurnal Sains Manajemen Informatika dan Komputer), 19(1), 88-99.

[6] Najoan, Rudy. 2015. Seni Bonsai Indonesia Teori, Aplikasi, dan Apresiasi Tangerang Selatan : PT Kaurama Buana Antara

[7] Siregar, E. T. (2015). Penerapan Teorema Bayes Pada Sistem Pakar Untuk Mengidentifikasi Penyakit Tumbuhan Padi. Seminar Nasional Informatika, 23-26. 